\section{Use of dental services and associated factors among elderly in southern Brazil}

\section{Utilização dos serviços odontológicos e fatores associados em idosos do Sul do Brasil}

\section{Alexandre Emidio Ribeiro Silva' \\ Caroline de Oliveira Langlois' \\ Carlos Alberto Feldens'}

'Programa de Pós-Graduação em Odontologia, Universidade Luterana do Brasil - Canoas (RS), Brazil.

\section{Abstract}

Objective: To analyze the use of dental services and associated factors among elderly treated at Family Health Units in southern Brazil. Methods: This cross-sectional study evaluated 438 elderly attending Family Health Units in Pelotas, southern Brazil. Data were collected using a standardized questionnaire covering demographic and socioeconomic variables, in addition to information on time elapsed since their last dental visit. Explanatory variables were classified according to Andersen and Davidson's model. Clinical variables were obtained by a trained dentist. Multivariable Poisson regression models with robust variance were used to identify factors associated with the outcome. Results: The prevalence of use of dental services in the last 3 years was $41.1 \%$ (95\%CI 36.5 - 45.7). Multivariable analysis revealed that the probability of not using dental services was higher among individuals who self-assessed their general health as poor or very poor (Prevalence Ratio $[\mathrm{PR}]=1.36 ; 95 \% \mathrm{CI}$ 1.05 - 1.78), with less than 8 years of education (< 4 years: $\mathrm{PR}=1.43 ; 95 \% \mathrm{CI} 1.01-2.02 ; 4$ to 7 years: $\mathrm{PR}=1.43 ; 95 \% \mathrm{CI} 1.00-2.04)$, users of alcohol (PR = 1.31; 95\%CI 1.08 - 1.59), and those with no teeth $(\mathrm{PR}=1.73 ; 95 \% \mathrm{CI} 1.29$ 2.32). Conclusions: The low prevalence of use of dental services among elderly attending Family Health Units in Pelotas, especially among those with poor self-assessed general health, lower education level, and without teeth, indicate the need for public policies to improve social indicators and general health.

Keywords: Elderly. Oral health. Dental care. Epidemiology. Cross-sectional studies. Family Health. 


\section{Resumo}

Objetivo: Analisar o uso de serviços odontológicos e fatores associados entre idosos atendidos em Unidades de Saúde da Família no sul do Brasil. Métodos: Este estudo transversal avaliou 438 idosos que frequentam unidades de saúde da família em Pelotas, sul do Brasil. Os dados foram coletados por meio de um questionário padronizado sobre aspectos demográficos e socioeconômicos, além de informações sobre o tempo decorrido desde a sua última visita ao dentista. As variáveis explicativas foram classificadas de acordo com modelo de Andersen e Davidson. As variáveis clínicas foram obtidas por um dentista treinado. Regressão de Poisson com variância robusta foi usada para identificar fatores associados com o desfecho. Resultados: A prevalência do uso dos serviços odontológicos há menos de três anos foi de 41,1\% (IC95\% 36,5 - 45,7). Análise multivariável demonstrou que a probabilidade de não ter usado serviços odontológicos foi maior em indivíduos que autopercebiam a saúde geral como ruim ou muito ruim (Razão de Prevalências $[R P]=1,36$; IC95\% 1,05 - 1,78), tinham menos de 8 anos de escolaridade ( $<4$ anos: $\mathrm{RP}=1,43$; IC95\% 1,01 - 2,02; 4 a 7 anos: $R P=1,43$; IC95\% 1,00 - 2,04), fizeram uso de álcool $(\mathrm{RP}=1,31$; IC95\% 1,08 - 1,59) e não apresentavam dentes $(\mathrm{RP}=1,73$; IC95\% 1,29 - 2,32). Conclusões: Abaixa prevalência de uso de serviços odontológicos entre idosos que frequentam Unidades de Saúde da Família de Pelotas, especialmente entre aqueles com autopercepção da saúde geral pobre, baixo nível de escolaridade e sem dentes, indica a necessidade de políticas públicas para melhorar osindicadores sociais egerais de saúde.

Palavras-chave: Idoso. Saúde bucal. Assistência odontológica. Epidemiologia. Estudos Transversais. Saúde da família.

\section{Introduction}

Health services in Brazil have not appropriately met the needs of the elderly population ${ }^{1}$. Specifically in the field of oral health, attention and assistance to the elderly require specialized and expensive treatments for oral health rehabilitation, especially considering the high rates of edentulism in this age range ${ }^{2}$. The last national oral health survey conducted in Brazil (SB Brasil 2010) found that $30.4 \%$ of the participants aged 65 - 74 years had visited the dentist in the past year and $59.4 \%$ had been treated in the private sector; tooth extraction was the second most frequent treatment, and only $7.3 \%$ of the elderly did not require any type of dental prosthesis ${ }^{3}$.

An increased access to health care services, represented by the relationship between number of users and number of health system facilities, is paramount to improve oral health indicators ${ }^{4}$. The use of dental services is a right of Brazilian citizens. Dental care should aim to relieve pain and suffering and also to restore the individuals' oral health ${ }^{5}$. Appropriate, regular use of dental services at all ages is known to contribute to the prevention and treatment of major oral health problems ${ }^{6}$.

Studies have used the model proposed by Andersen and Davidson ${ }^{7}$ to assess determinant factors of the use of oral health services. According to that model, access to and use of health care services require the combination of several factors: external environmental factors (general health factors); individual characteristics, divided into predisposing factors (sociocultural characteristics), availability factors, or factors that facilitate the use of services (income, health insurance, regular access to health services), and factors related to need for treatment (self-assessment about the need for dental treatment); factors related to the oral health care system (oral health policies and resources); personal practices (oral hygiene and poor oral health behaviors); and both clinically evaluated oral health status and self-assessed oral health.

Few studies have investigated oral health data in elderly populations served by 
public Family Health Units of the Brazilian Unified Health System, whose health care services excel in multidisciplinary work, comprehensive care, and improved health indicators. Therefore, the present study was conducted to estimate the prevalence of use of dental services among elderly treated at Family Health Units in the urban area of Pelotas, southern Brazil, as well as to investigate factors associated with the outcome according to the model proposed by Andersen and Davidson?

\section{Methodology}

\section{Study Design and Participants}

This cross-sectional study included all Family Health Units located in the urban area of Pelotas, state of Rio Grande do Sul, southern Brazil. The municipality has a population of 327,778 inhabitants ${ }^{8}$, and approximately 37,715 are aged 60 years or more.

The study was conducted between May 2009 and September 2010. Participants included individuals aged 60 years or older, randomly selected from a list of 3,744 eligible elderly enrolled in 23 Family Health Units. Inclusion criteria were being independent, being able to perform activities of daily living (bathing, feeding, etc.) without assistance of a relative or caregiver, walking without assistance, and having cognitive conditions to answer the questionnaire.

\section{Sample}

The following parameters were considered during sample size calculation: $\alpha=5 \%, 80 \%$ power, a prevalence of less frequent use of dental services of $68 \%$ in the unexposed group (individuals with natural teeth) ${ }^{9}$, a prevalence

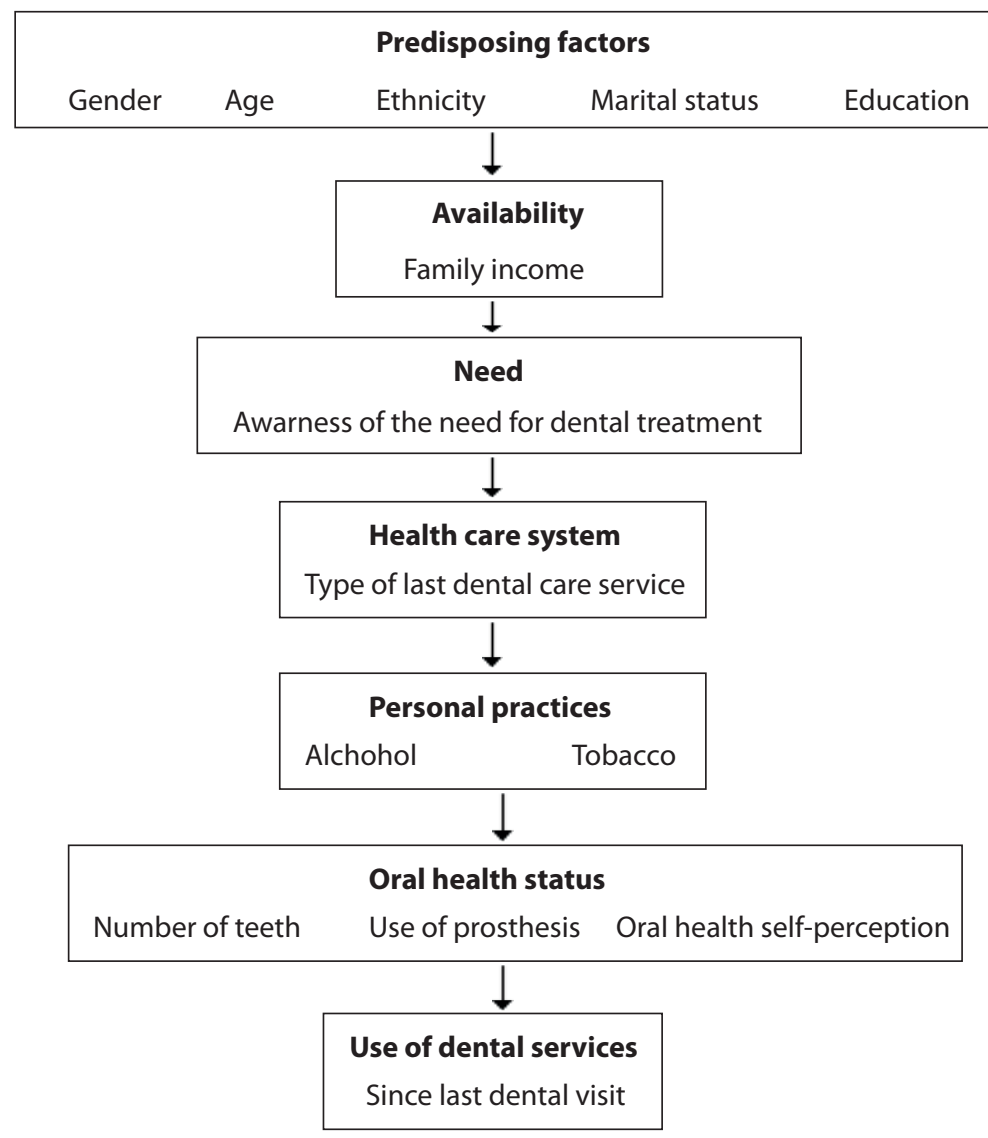

Figure 1 - Hierarchical model for determination of the use of dental services (adapted from Andersen and Davidson), 2010. Figura 1 - Modelo hierárquico de determinação da utilização dos serviços odontológicos (adaptado do modelo de Andersen e Davidson), 2010. 
ratio of 1.2 in the exposed group (edentulous patients) and a 1:1 ratio of exposed to unexposed, requiring a minimum sample size of 346 individuals. This number was increased by $25 \%$ for multivariate analysis, resulting in a sample size of 432 individuals. Moreover, we estimated that $10 \%$ of the individuals would not present all inclusion criteria and that we would have a $30 \%$ loss rate (including refusals). As a result, the names of 700 elderly were drawn.

Sampling was performed using the stratified simple random method and a table of random numbers. The number of individuals selected at each Family Health Unit was proportional to the number of people aged 60 years or older and to the number of men and women served by the unit.

\section{Data Collection}

A standardized questionnaire was used to obtain demographic and socioeconomic variables and data related to the use of dental services (self-assessed need for treatment and self-assessed oral health). This data collection tool has closed-ended questions that have demonstrated satisfactory reliability in previous studies of good methodological qualtiy ${ }^{10-14}$. The questionnaire was tested in a pilot study conducted at a health care facility, with elderly that were not selected for the sample, in order to assess whether all elders would understand the terms and questions contained in the instrument, as well as to train the research team. Following implementation of changes resulting from instrument application in the pilot study, interviews were conducted at the participants' homes by trained interviewers. Questionnaire application was repeated via phone calls in $10 \%$ of the population sampled to assess instrument reproducibility and participant satisfaction, and also to identify potential mistakes made by the interviewers. The elderly were invited for an appointment at the Family Health Unit to assess the number of natural teeth and the need for a dental prosthesis. Physical examination was conducted by a dentist with theoretical and practical training using personal protective equipment (gloves, mask, hat, and apron), tweezers, and a CPI periodontal probe, with participants sitting, under natural light. The World Health Organization criteria for epidemiological surveys on oral health ${ }^{15}$ were used to determine the need of prosthesis.

\section{Outcome: Last Dental Visit}

The outcome variable was defined by the time elapsed since the participant's last dental visit, obtained with the following question: "How many months ago did you last visit the dentist?" For purposes of analysis, this variable was categorized as having last visited the dentist in the previous three years or more than three years.

\section{Explanatory Variables}

Variables were classified according to the model proposed by Andersen and Davidson ${ }^{7}$ as follows: 1) external environmental factors: depression (yes or no), chronic disease (yes or no), self-perceived general health (very good, good and proper, or very poor and poor); individual characteristics: 2) predisposing factors: gender (male or female), age (60 to 69,70 to 79 , or 80 years or older), marital status (single, married or living with a partner/spouse, divorced or widowed; subsequently classified as without partner or with partner), self-reported ethnicity according to the classification of the Brazilian Institute of Geography and Statistics (IBGE) (white, yellow, brown, indigenous, or not declared; subsequently classified as white or non-white), years of education $(<4,4-7$, or $\geq 8)$;3) availability variables: family income, collected in Brazilian currency (BRL) and then divided by the reference minimum wage in Brazil (later categorized in $<1.0$, 1.0 to 1.5 , or 1.5 or more minimum wages per capita); 4) need: awareness of the need for dental treatment (yes or no); 5) health care system: type of service last used (public or private); 6) personal practices: tobacco consumption (yes, no, or former smoker) and alcohol consumption, regardless of the amount of alcohol consumed (yes, no, or 
former user); and 7) oral health status: number of natural teeth in the oral cavity (no teeth, 1-9 teeth, or 10 teeth or more), use of any type of prosthesis (yes or no), and self-assessed oral health compared to other people in the same age group (very good, good, adequate, or very poor and poor).

Depressive symptoms were assessed using the Geriatric Depression Scale (GDS), comprised of 15 questions, validated for use in Brazil by Almeida and Almeida in $1999^{11}$. Individuals scoring 5 or higher were considered to have symptoms of depression according to the criteria of the International Classification of Diseases, 10th edition (ICD-10) ${ }^{16}$.

\section{Statistical Analysis}

Data were analyzed using the Statistical Package for the Social Sciences (SPSS) version 16.0 (SPSS Inc., Chicago, Ill). First, a descriptive analysis was performed, and results were expressed as relative and absolute frequencies. Subsequently, a bivariate analysis was performed using Pearson's $\chi^{2}$ test and the trend test to check for associated factors. Finally, non-adjusted and adjusted Poisson regression models with robust variance were used.

All variables showing $\mathrm{p}<0.20$ in the bivariate analysis were considered potential confounders and therefore included in the multivariate analysis for the calculation of Prevalence Ratios (PR) and 95\% Confidence Intervals (95\%CI). A hierarchical approach, based on the theoretical model of Andersen and Davidson ${ }^{7}$, was used in the analysis (Figure 1). External environmental variables were considered in the first (most distal) level of the model. Predisposing variables were included in the second (intermediate) level, availability variables in the third, and need variables in the fourth level. Health care system variables were included in the fifth level, personal practices in the sixth, and oral status variables in the most proximal level. Variables were adjusted for the same level and levels above. Variables showing $\mathrm{p}<0.05$ in at least one category were included in the final model.

Collinearity analysis for independent variables was performed using the variance inflation factor (VIF). Values near or above 10 were considered to indicate strong collinearity. The following adjustment measures were calculated to assess the quality of the final model: adjusted and unadjusted pseudo R-squared, Akaike information criterion (AIC), and mean square error (MSE).

\section{Ethical Aspects}

Authors declared no conflicts of interest. The project was approved by the Research Ethics Committee of Universidade Luterana do Brasil (protocol no. 2009-193H). Informed consent forms were signed by all participants before their inclusion in the study.

\section{Results}

Overall response rate was $70 \%(489 / 700)$. The main reasons for losses were refusal to participate $(\mathrm{n}=111 ; 16 \%)$ and change of address $(n=84 ; 12 \%)$. No differences were found between the selected individuals and the source population regarding gender $(\mathrm{p}=$ $0.130)$ or age $(p=0.109)$. In 51 of 489 individuals, dependence status or cognitive conditions prevented inclusion in the study. As a result, the final study sample comprised 438 elderly, predominantly women (68.3\%), aged 60 - 69 years $(57.4 \%)$, Caucasian ( $71.2 \%$ ), with a family income of 0 to 1.5 minimum wages per capita (59.6\%), 4 to 7 years of education (54.1\%), without depressive symptoms (71.0\%), with no natural teeth $(51.2 \%)$, and using prosthesis (84.7\%).

The prevalence of use of dental services during the previous three years was $41.1 \%$ (95\%CI 36.5 - 45.7). Variables associated with last dental visit in the previous three years, according to the $\chi^{2}$ test, were selfassessed general health $(\mathrm{p}=0.019)$, level of education ( $p=0.035)$, minimum wages per capita $(\mathrm{p}=0.042)$, and number of teeth $(\mathrm{p}<0.001)$. Other variables included in the multivariate model were depressive symptoms, alcohol consumption, type of service last used, and marital status (all p < 0.20) (Table 1). The unadjusted model showed that a poor or very poor selfassessed general health $(\mathrm{PR}=1.36 ; 95 \% \mathrm{CI}$ 
Table 1 - Sample characteristics, bivariate analysis ( $\chi^{2}$ test) and Poisson regression results (crude prevalence ratio, crude PR) for variables associated with use of dental services $>3$ years among elderly enrolled in Family Health Units of Pelotas, RS. 2010.

Tabela 1 - Descrição da amostra, da análise bivariada (teste $\chi^{2}$ ) e da regressão de Poisson (Razão de Prevalência Bruta) das características associadas ao uso de serviços odontológicos de idosos há mais de 3 anos pertencentes às unidades Saúde da Família da área urbana de Pelotas - RS. Pelotas - RS, 2010.

\begin{tabular}{|c|c|c|c|c|c|}
\hline \multirow{2}{*}{ Variables (n) } & \multirow{2}{*}{ n (\%) } & \multicolumn{2}{|c|}{ Use of dental services } & \multicolumn{2}{|c|}{ Use of dental services $>3$ years } \\
\hline & & $\leq 3$ years before & $>3$ years before & Crude PR $(95 \% \mathrm{Cl})$ & $p$-value ${ }^{* * *}$ \\
\hline \multicolumn{6}{|l|}{ External environment } \\
\hline Depressive symptom & \multicolumn{3}{|c|}{$p=0.124^{*}$} & & \multirow{3}{*}{0.110} \\
\hline No & $311(71.0)$ & $135(43.4)$ & $176(56.6)$ & 1.0 & \\
\hline Yes & $127(29.0)$ & $45(35.4)$ & $82(64.6)$ & $1.14(0.97-1.34)$ & \\
\hline \multicolumn{2}{|c|}{ Chronic disease $(n=436)$} & \multicolumn{2}{|c|}{$p=0.648^{*}$} & & \\
\hline No & $97(22.2)$ & $42(43.3)$ & $55(56.7)$ & 1.0 & \multirow[t]{2}{*}{0.654} \\
\hline Yes & $339(77.8)$ & $138(40.7)$ & $201(59.3)$ & $1.05(0.86-1.27)$ & \\
\hline \multicolumn{2}{|c|}{ General health self-assessment $(n=438)$} & \multicolumn{2}{|c|}{$p=0.019^{*}$} & & \\
\hline Very good & $61(13.9)$ & $26(42.6)$ & $35(57.4)$ & 1.0 & 0.001 \\
\hline Good and proper & $331(75.6)$ & $144(43.5)$ & $187(56.5)$ & $0.98(0.78-1.25)$ & \\
\hline Very poor and poor & $46(10.5)$ & $10(21.7)$ & $36(78.3)$ & $1.36(1.05-1.78)$ & \\
\hline \multicolumn{6}{|l|}{ Predisposing } \\
\hline \multicolumn{2}{|l|}{ Gender $(n=438)$} & \multicolumn{2}{|c|}{$p=0.695^{*}$} & & \multirow{3}{*}{0.698} \\
\hline Female & $299(68.3)$ & $121(40.1)$ & $178(59.9)$ & 1.0 & \\
\hline Male & $139(31.7)$ & $59(42.4)$ & $80(57.6)$ & $0.97(0.81-1.15)$ & \\
\hline \multicolumn{2}{|l|}{ Age $(n=437)$} & \multicolumn{2}{|c|}{$p=0.429^{* *}$} & & \multirow{4}{*}{0.424} \\
\hline $60-69$ & $251(57.4)$ & $110(43.8)$ & $141(56.2)$ & 1.0 & \\
\hline $70-79$ & $138(31.6)$ & $52(37.7)$ & $86(62.3)$ & $1.11(0.94-1.31)$ & \\
\hline$\geq 80$ & $48(11.0)$ & $18(37.5)$ & $30(62.5)$ & $1.11(0.87-1.42)$ & \\
\hline \multicolumn{2}{|l|}{ Marital status $(n=437)$} & \multicolumn{2}{|c|}{$p=0.132^{*}$} & & \multirow{3}{*}{0.135} \\
\hline With partner & $230(52.6)$ & $87(37.8)$ & $143(62.2)$ & 1.0 & \\
\hline Without partner & $207(47.4)$ & $93(44.9)$ & $114(55.1)$ & $0.89(0.76-1.04)$ & \\
\hline \multicolumn{2}{|l|}{ Ethnicity $(n=438)$} & \multicolumn{2}{|c|}{$\mathrm{p}=0.417^{*}$} & & \\
\hline White & $312(71.2)$ & $132(42.2)$ & $180(57.8)$ & 1.0 & 0.408 \\
\hline Non-white & $126(28.8)$ & $48(38.7)$ & $78(61.3)$ & $1.07(0.91-1.27)$ & \\
\hline \multicolumn{2}{|c|}{ Education (years) $(n=438)$} & \multicolumn{2}{|c|}{$p=0.035^{* *}$} & & \\
\hline$<4$ & $153(34.9)$ & $61(40.0)$ & $92(60.0)$ & $1.44(1.01-2.07)$ & 0.090 \\
\hline $4-7$ & $237(54.1)$ & $91(38.4)$ & $146(61.6)$ & $1.48(1.04-2.10)$ & \\
\hline$\geq 8$ & $48(11.0)$ & $28(58.3)$ & $20(41.7)$ & 1.0 & \\
\hline \multicolumn{6}{|l|}{ Availability } \\
\hline \multicolumn{2}{|c|}{$\begin{array}{l}\text { Family income } \\
\text { (minimum wages) per capita }(n=438)\end{array}$} & $p=0$ & $42^{* *}$ & & \\
\hline$<1$ & $78(17.9)$ & $29(37.2)$ & $49(62.8)$ & 1.0 & 0.074 \\
\hline $1-1.5$ & $260(59.6)$ & $99(38.1)$ & $161(61.9)$ & $0.99(0.81-1.20)$ & \\
\hline$>1.5$ & $98(22.5)$ & $51(52.0)$ & $47(48.0)$ & $0.76(0.58-0.99)$ & \\
\hline
\end{tabular}


Table 1 - Continuation.

Tabela 1 - Continuação.

\begin{tabular}{|c|c|c|c|c|c|}
\hline \multirow{2}{*}{ Variables } & \multirow{2}{*}{$\mathrm{n}(\%)$} & \multicolumn{2}{|c|}{ Use of dental services } & \multicolumn{2}{|c|}{ Use of dental services $>3$ years } \\
\hline & & $\leq 3$ years before & $>3$ years before & Crude PR $(95 \% \mathrm{Cl})$ & $p$-value ${ }^{* * *}$ \\
\hline \multicolumn{6}{|l|}{ Need } \\
\hline \multicolumn{2}{|c|}{$\begin{array}{l}\text { Awareness of the need } \\
\text { for dental treatment }(n=438)\end{array}$} & \multicolumn{2}{|c|}{$p=0.278^{*}$} & & \\
\hline No & $218(49.80)$ & $84(38.5)$ & $134(61.5)$ & 1.0 & 0.279 \\
\hline Yes & $220(50.20)$ & $96(43.6)$ & $124(56.4)$ & $0.92(0.78-1.07)$ & \\
\hline \multicolumn{6}{|l|}{ Health care system } \\
\hline \multicolumn{2}{|c|}{ Type of last dental service used $(n=433)$} & \multicolumn{2}{|c|}{$p=0.072^{*}$} & & \\
\hline Public & $188(43.4)$ & $69(36.7)$ & $119(63.3)$ & 1.0 & 0.070 \\
\hline Private & $245(56.6)$ & $111(45.3)$ & $134(54.7)$ & $0.86(0.74-1.01)$ & \\
\hline \multicolumn{6}{|l|}{ Personal practices } \\
\hline \multicolumn{2}{|c|}{ Tobacco consumption $(\mathrm{n}=438$ ) } & \multicolumn{2}{|c|}{$p=0.806^{*}$} & & \\
\hline No & $294(67.1)$ & $124(42.2)$ & $170(57.8)$ & 1.0 & 0.801 \\
\hline Former smoker & $85(19.4)$ & $33(38.8)$ & $52(61.2)$ & $1.06(0.87-1.29)$ & \\
\hline Yes & $59(13.5)$ & $23(39.0)$ & $36(61.0)$ & $1.06(0.84-1.32)$ & \\
\hline \multicolumn{2}{|c|}{ Alcohol consumption $(n=438)$} & \multicolumn{2}{|c|}{$p=0.056^{*}$} & & \\
\hline No & $351(80.1)$ & $150(42.7)$ & $201(57.3)$ & 1.0 & 0.001 \\
\hline Former consumer & $39(8.9)$ & $9(23.1)$ & $30(76.9)$ & $1.34(1.11-1.63)$ & \\
\hline Yes & $48(11.0)$ & $21(43.7)$ & $27(56.3)$ & $0.98(0.75-1.28)$ & \\
\hline \multicolumn{6}{|l|}{ Oral health status } \\
\hline \multicolumn{2}{|c|}{ Number of teeth $(n=438)$} & \multicolumn{2}{|c|}{$p=0.000^{*}$} & & \\
\hline No teeth & $224(51.2)$ & $70(31.3)$ & $154(68.7)$ & $1.66(1.22-2.24)$ & 0.000 \\
\hline $1-9$ teeth & $149(34.0)$ & $72(48.3)$ & $77(51.3)$ & $1.24(0.90-.73)$ & \\
\hline 10 teeth or more & $65(14.8)$ & $38(58.5)$ & $27(41.5)$ & 1.0 & \\
\hline \multicolumn{2}{|c|}{ Use of prosthesis $(n=438)$} & \multicolumn{2}{|c|}{$p=0.693^{*}$} & & \\
\hline Yes & $371(84.7)$ & $151(40.7)$ & $220(59.3)$ & 1.0 & 0.700 \\
\hline No & $67(15.3)$ & $29(43.3)$ & $38(56.7)$ & $0.96(0.76-1.20)$ & \\
\hline \multicolumn{2}{|c|}{ Oral health self-perception $(n=438)$} & \multicolumn{2}{|c|}{$p=0.241^{*}$} & & \\
\hline Very good & $68(15.5)$ & $31(45.6)$ & $37(54.4)$ & 1.0 & 0.177 \\
\hline Good/adequate & $321(73.3)$ & $134(41.7)$ & $187(58.3)$ & $1.07(0.84-1.36)$ & \\
\hline Very poor/poor & $49(11.2)$ & $15(30.6)$ & $34(69.4)$ & $1.28(0.96-1.70)$ & \\
\hline
\end{tabular}

*Pearson's $\chi^{2}$ test; ${ }^{* *} \chi^{2}$ test for linear trend; ${ }^{* *} \S W a l d ' s$ test.

*Teste $\chi^{2}$ de Pearson; ${ }^{* *}$ teste $\chi^{2}$ de tendência linear; ${ }^{* * *}$ teste de wald.

1.05 - 1.78), less than 8 years of education (less than 4 years of study, $\mathrm{PR}=1.44,95 \% \mathrm{CI}$ $1.01-2.07 ; 4$ to 7 years of study, PR $=1.48$, 95\%CI $1.04-2.10$ ), previous consumption of alcohol (PR = 1.34, 95\%CI $1.11-1.63)$, and absence of natural teeth (PR $=1.66,95 \% \mathrm{CI} 1.22$ 2.24) were associated with an increased time elapsed since the last dental visit. In the final model (Table 2), the probability of not having used dental services in the past three years was higher in individuals who self-assessed their general health as poor or very poor $(\mathrm{PR}=$ 1.36, 95\%CI $1.05-1,78$ ), who had less than 8 years of education (less than 4 years of study, $\mathrm{PR}=1.43,95 \% \mathrm{CI} 1.01-2.02 ; 4$ to 7 years of study, PR $=1.43,95 \%$ CI $1.00-2.04$ ), who 
Table 2 - Adjusted prevalence ratios for independent variables associated with use of dental services $>3$ years among elderly enrolled in Family Health Units of Pelotas - RS, 2010.

Tabela 2 - Razões de Prevalência ajustadas das variáveis independentes associadas ao uso de serviços odontológicos há mais de 3 anos por idosos pertencentes às unidades Saúde da Família da área urbana de Pelotas - RS, 2010.

\begin{tabular}{|c|c|c|}
\hline \multirow{2}{*}{ Variables } & \multicolumn{2}{|c|}{ Use of dental services $>3$ years } \\
\hline & Adjusted PR $(95 \% \mathrm{Cl})$ & $p$-value* \\
\hline \multicolumn{3}{|l|}{ External environment } \\
\hline \multicolumn{3}{|c|}{ General health self-assessment } \\
\hline Very good & 1.0 & \\
\hline Good and proper & $0.98(0.78-1.25)$ & 0.898 \\
\hline Very poor and poor & $1.36(1.05-1.78)$ & 0.022 \\
\hline \multicolumn{3}{|l|}{ Predisposing } \\
\hline \multicolumn{3}{|l|}{ Education (years) } \\
\hline$<4$ & $1.43(1.01-2.02)$ & 0.043 \\
\hline $4-7$ & $1.43(1.00-2.04)$ & 0.047 \\
\hline$\geq 8$ & 1.0 & \\
\hline \multicolumn{3}{|l|}{ Personal practices } \\
\hline \multicolumn{3}{|l|}{ Alcohol consumption } \\
\hline No & 1.0 & \\
\hline Former consumer & $1.31(1.08-1.60)$ & 0.007 \\
\hline Yes & $1.07(0.82-1.40)$ & 0.628 \\
\hline \multicolumn{3}{|l|}{ Oral health status } \\
\hline \multicolumn{3}{|l|}{ Number of teeth } \\
\hline No teeth & $1.73(1.29-2.32)$ & 0.000 \\
\hline $1-9$ teeth & $1.27(0.92-1.73)$ & 0.135 \\
\hline 10 teeth or more & 1.0 & \\
\hline
\end{tabular}

* Variables adjusted for the same level and levels above.

*Varáveis ajustadas para o mesmo nível e níveis acima.

were former consumers of alcohol $(\mathrm{PR}=1.31$; $95 \%$ CI 1.08 - 1.59), and who did not have natural teeth (PR $=1.73 ; 95 \% \mathrm{CI} 1.29-2.32)$, considering the theoretical model of access and individual use of health services proposed by Andersen and Davidson? .

Collinearity analysis showed no significant correlation among the independent variables (all variables showed VIF < 2). Once the final model had been obtained, we performed one additional analysis, removing the alcohol consumption variable, as response options were non-discriminatory. However, this new model proved worse than thefinal one because itshowed lowervalues for adjusted and unadjusted pseudo R-squared and higher values for AIC and MSE.

\section{Discussion}

According to this study's findings, less than half of the elderly assessed had used dental services in the three years preceding the interview, and this outcome was influenced by general health perception, education level, alcohol consumption, and number of teeth. Other studies designed to assess the use of dental services have tended to focus on the previous year, a methodological difference that hampers comparisons with data observed here $^{6,9,17-21}$. There is not a universally accepted cutoff point for assessing time since last dental visit among elders, reflecting the absence of a standardized ideal frequency for this population. However, some studies have reported that elders remain long periods without using dental services ${ }^{2,22}$, and have suggested that 12 months is too short for an adequate analysis of this population ${ }^{22}$. The high rate of edentulism among the elderly (who supposedly attend dental services less frequently) should also be taken into consideration. These are the reasons why 
a cutoff point of three years was chosen in the present study.

The prevalence of use of dental services in the previous three years in Pelotas was higher than that recently described for elderly people from Ponta Grossa, state of Paraná, southern Brazil ${ }^{2}$, and for individuals aged $65-74$ years in China ${ }^{22}$. The higher level of education observed in this study, a factor that seems to influence the use of dental services, may have contributed to such difference.

Previous studies have suggested the importance of socioeconomic variables such as income and education as determinants for the use of dental services, regardless of age ${ }^{23-25}$. In the present study, the level of education proved to be a predictor of the use of dental services by the elderly, corroborating previous findings ${ }^{9,17,21,22,26,27}$. However, this finding should be interpreted based on the context of the population, which was characterized by a homogeneous, predominantly low socioeconomic status ${ }^{28}$. It is possible that the strength of the association would be even greater in populations with more heterogeneous characteristics. Even though income and education are widely recognized as having different meanings, where income indicates the purchasing power and education is more related to health care ${ }^{29}$, the link between both variables is undeniable, and can explain, at least in part, the loss of significance observed for the variable income in the model used in this study ${ }^{24}$. This reinforces the idea that people with higher levels of education tend to be more informed and aware of prevention measures and of the need for treating problems affecting the oral health than those with lower education levels ${ }^{30}$.

Of the variables present in Andersen and Davidson's model ${ }^{7}$, self-perceived general health was associated with increased time since the last dental visit. A poor selfassessment of general health seems to reduce the frequency of use of oral health services due to the lesser importance attributed to oral health problems and to these patients' greater difficulty in accessing oral health services because of their general health problems ${ }^{17,31}$.
The observation that depressive symptoms negatively influence the use of dental services has recently been reported for Mexican elderly people $^{18}$. Thisfinding is not exclusive to oral health services. In fact, the literature has identified that elderly with depressive symptoms also attend fewer health services, often due to financial difficulties and because depressive symptoms are not diagnosed in the basic care services ${ }^{32}$.

Considering that the elderly are the greatest consumers of medical services $^{18}$, one possible implication of the results of this study refers to the potential contribution of general health professionals towards a better oral health care. It is possible that medical advice recommending regular dental visits, regardless of the presence or absence of teeth or of the use of prostheses, may contribute to a higher frequency of dental care.

The observation that former consumers of alcohol had a higher probability of taking longer to use dental services when compared with those who never consumed alcohol and with current consumers does notfind support in the literature. It is possible that, at least in part, a limitation in the question used to assess alcohol consumption in our research instrument(non-discriminatory answers) can explain the results observed.

The belief that the absence of teeth renders dental visits unnecessary has been reported in the literature as an important determinant of a low prevalence of dental service use

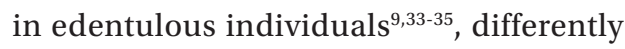
from individuals with teeth ${ }^{21,36}$ or from those using prostheses ${ }^{20}$. These findings have been confirmed in this study, in which edentulous individuals showed a $73 \%$ higher probability of not having visited the dentist in the previous three years when compared with those who had 10 teeth or more. Among the implications of this phenomenon, we can highlight a poor or non-existent monitoring of prostheses, concomitantly to the risk that relevant health problems, such as cancer injuries, may be detected only at an advanced stage, hindering or even preventing appropriate treatment.

Our results did not show any association between self-perceived need for dental treatment and use of dental services in the period assessed, differing from previously reported results ${ }^{24,34}$. The high rate of edentulism 
observed in our population may also have contributed to such different finding. Despite recent efforts made in Brazil to expand access to proper oral health care, with an increase in the number of oral health teams as part of the family health strategy and the Brasil Sorridente program (availability of specialized dental care centers), most of the elderly reported the use of private services, which is consistent with previous studies with other populations ${ }^{18,37}$.

Among the possible explanations for the infrequent use of public services among elderly people without or with few teeth is the fact that oral health teams working in the family health strategydonot offer prostheses, the mostfrequent need of this population group. This hypothesis maybeinvestigated infuture studies. According to results of the SB Brasil 2010 survey, the Brazilian Ministry of Health has invested heavily in the accreditation of prosthetic laboratories and has been developing actions so as to qualify basic health professionals to produce prostheses ${ }^{3}$. In this sense, a positive outlook for the next generations of elderly is the fact that international studies have shown a relationship between an increased number of visits to the dentist during childhood and a higher number of teeth in subsequent life stages ${ }^{38}$. However, the rates of oral health care service use among preschool children in Brazil are still very low, representing another challenge to be faced ${ }^{39}$.

Unlike other studies, no association was found in the sample between gender ${ }^{17}$ and age ${ }^{17,19}$ and time elapsed since the last dental visit. Even though women of all age ranges tend to seek dental services more often than men ${ }^{5,40}$, elderly of both genders have equal opportunities of access to the health care system. If, in one hand during adult life, the opening hours of health care units may indeed represent a barrier to professionally active individuals (predominantly men), on the other hand this difficulty seems to lessen and even disappear with increasing age ${ }^{40}$.

In this study, the elderly accounted for a large portion of the population served by the Family Health Units in Pelotas. The units had multidisciplinary teams and developed health promotion, disease prevention and health recovery programs at neighborhood associations and at the families' homes. It is therefore possible that, as oralhealth teams areincreasinglyqualified, a more frequent use of dental services will occur. Although two recent studies ${ }^{41,42}$ have observed that the availability of oral health teams did not increase access to oral health services in some age groups, including the elderly, one must take into account that these teams, when compared to basic health care units, still reproduce the traditional model of care, directing most actions to school-aged populations ${ }^{41}$.

Some methodological limitations are noteworthy. Firstly, the cross-sectional design of the study does not allow determining temporal relationships between exposures and outcomes. The findings should therefore be interpreted with caution, as some form of reverse causality may have occurred. Secondly, because the outcome was dependent on the participants' memory regarding the last time they had visited a dentist, the possibility of recall bias should not be dismissed and may have affected the prevalence rates obtained. Thirdly, while the questions on self-assessed oral health and general health status have been previously tested and demonstrated satisfactory reliability in different age groups, the reliability may be somewhat lesser in elderly individuals ${ }^{13,14}$. However, if any misclassifications happened with the variable self-assessment, it would have been probably a non-differential error. As this type of error would bias the study results towards the null hypothesis ${ }^{43}$, it can be inferred that it did not influence the reported associations.

In conclusion, the results of this study demonstrated low rates of use of oral health services among the elderly, especially those with low education levels, with a poor self-assessed general health, and without or with few teeth, pointingtomajorinequitiestobefaced. In addition to improving the health caremodel and increasing the number of oral and general health services available, the scope of public policies should include improvement of income and education indicators, which have much more positive effects in reducinginequalities.Suchimprovementwould not only increase access to health services, but also the awareness of the fact that, even in the absence of teeth, regular attendance to dental services is extremely important for rehabilitation and oral health maintenance. 


\section{References}

1. Colussi CF, Freitas SFT, Calvo MCM. Perfil epidemiológico da cárie e do uso e necessidade de prótese na população idosa de Biguaçu, Santa Catarina. Rev Bras Epidemiol 2004; 7: 88-97.

2. Baldani MH, Brito WH, Lawder JAC, Mendes YBEI, Silva FFM, Antunes JLF. Determinantes individuais da utilização de serviços odontológicos por adultos e idosos de baixa renda. Rev Bras Epidemiol 2010; 13: 150-62.

3. Brasil. Ministério da Saúde. Pesquisa Nacional de Saúde Bucal 2010 [cited 2012Mar25]. Available from: http://189.28.128.100/dab/docs/geral/projeto_sb2010_ relatorio_final.pdf

4. Manhães ALD, Costa AJL. Acesso e utilização de serviços odontológicos no Estado do Rio de Janeiro, Brasil, em 1998: um estudo exploratório a partir da Pesquisa Nacional por Amostra de Domicílios. Cad Saúde Pública 2008; 24: 207-18.

5. Araujo CS, Lima RC, Peres MA, Barros AJD. Utilização de serviços odontológicos e fatores associados: um estudo de base populacional no Sul do Brasil. Cad Saúde Pública 2009; 25: 1063-72.

6. Martins AMEBL, Barreto SM, Pordeus IA. Uso de serviços odontológicos entre idosos brasileiros. Rev Panam Salud Publica 2007; 22: 308-16.

7. Andersen RM, Davidson PL. Ethnicity, aging, and oral health outcomes: A conceptual framework. Adv Dent Res 1997; 11: 203-9.

8. IBGE. Instituto Brasileiro de Geografia e Estatística. Censo Demográfico 2010 [cited 2010Dec31]. Available from: http:// www.ibge.gov.br/cidadesat/topwindow.htm?1

9. Martins AMEBL, Barreto SM, Pordeus IA. Características associadas ao uso de serviços odontológicos entre idosos dentados e edentados no Sudeste do Brasil: Projeto SB Brasil. Cad Saúde Pública 2008; 24: 81-92.

10. Locker D, Gibson B. Discrepancies between self-ratings of and satisfaction with oral health in two older adult populations. Community Dent Oral Epidemiol 2005; 33: 280-8.

11. Almeida OP, Almeida SA. [Reliability of the Brazilian version of the ++abbreviated form of Geriatric Depression Scale (GDS) short form]. Arq Neuropsiquiatr 1999; 57(2B): 421-6.

12. Santos SM, Chor D, Werneck GL, Coutinho ESF. Associação entre fatores contextuais e auto-avaliação de saúde: uma revisão sistemática de estudos multinível. Cad Saúde Pública. 2007; 23: 2533-54.

13. Martikainen P, A Aromaa A, Heliovaara M, Klaukka T, Knekt P, Maatela J, et al. Reliability of perceived health by sex and age. Soc Sci Med 1999; 48: 1117-22.

14. Afonso-Souza, G, Nadanovsky P, Werneck GL, Faerstein E, Chor D, Lopes CS. Test-retest reliability of self-perceived oral health in an adult population in Rio de Janeiro, Brazil. Cad Saúde Pública 2007; 23: 1483-8.
15. World Health Organization. Calibration of examiners for oral health epidemiological surveys. Geneva: ORH/EPID, 1993.

16. Almeida OP, Almeida SA. Short versions of the geriatric depression scale: a study of their validity for the diagnosis of a major depressive episode according to ICD-10 and DSM-IV. Int J Geriatr Psychiatry 1999a; 14: 858-65.

17. Matos DL, Lima-Costa MF. Tendência na utilização de serviços odontológicos entre idosos brasileiros e fatores associados: um estudo baseado na Pesquisa Nacional por Amostra de Domicílios (1998 e 2003). Cad Saúde Pública 2007; 23: 2740-8.

18. Sánchez-García S, Fuente-Hernández JL, Juárez-Cedillo T, Mendoza JMO, Reyes-Morales H, Solórzano-Santos F, et al. Oral health service utilization by elderly beneficiaries of the Mexican Institute of Social Security in México city. BMC Health Services Research 2007, 7: 211.

19. Matos DL, Giatti L, Lima-Costa MF. Fatores sóciodemográficos associados ao uso de serviços odontológicos entre idosos brasileiros: um estudo baseado na Pesquisa Nacional por Amostra de Domicílios. Cad Saúde Pública 2004; 20: 1290-7.

20. Locker D, Clarke M: Geographic variations in dental services provided to older adults in Ontario, Canada. Community Dent Oral Epidemiol 1999; 27: 275-82.

21. McGrath C, Bedi R, Dhawan N. Factors influencing older people's self reported use of dental services in the UK. Gerodontology 1999; 16: 97-102.

22. Lo ECM, Lin HC, Wan ZJ, Wong MCM, Schwarz E. Utilization of Dental Services in Southern China. J Dent Res 2001; 80:1471-4.

23. Campostrini, EP, Ferreira EF, Rocha FL. Condições da saúde bucal do idoso brasileiro. Arquivos em Odontologia 2007; 43: $48-56$.

24. Matos DL, Lima-Costa MFF, Guerra HL, Marcenes W. Projeto Bambuí: estudo de base populacional dos fatores associados com o uso regular de serviços odontológicos em adultos. Cad Saúde Pública 2001; 17: 661-8.

25. Barros AJD, Bertoldi AD. Desigualdades na utilização e no acesso a serviços odontológicos: uma avaliação em nível nacional. Ciênc Saúde Coletiva 2002; 7: 709-17.

26. Brothwell DJ, Jay M, Schönwetter DJ. Dental Service Utilization by Independently Dwelling Older Adults in Manitoba, Canada. JCDA 2008; 74: 161-161f.

27. Wu B, Tran TV; Khatutsky G. Comparison of Utilization of Dental Care Services Among Chinese- and RussianSpeaking Immigrant Elders. J Public Health Dent 2005; 65: 97-103.

28. Brasil. Ministério do Planejamento, Orçamento e Gestão. Instituto Brasileiro de Geografia e Estatística. Síntese de Indicadores Sociais. Uma análise das Condições de Vida da População Brasileira 2010. Rio de Janeiro. 2010. 
29. Camargo MBJ, Dumith SC, Barros AJD. Uso regular de serviços odontológicos entre adultos: padrões de utilização e tipos de serviços. Cad Saúde Pública 2009; 25:1894-906

30. Nitschke I, Muller F, Hopfenmuller W. The uptake of dental services by elderly Germans. Gerodontology 2001; 18: $114-20$

31. Strayer MS, Kuthy RA, Caswell RJ, Moeschberger ML. Predictors of Dental Use for Low-income, Urban Elderly Persons Upon Removal of Financial Barriers. The Gerontologist 1997; 37: 110-6.

32. Ojeda VD, McGuire TG. Gender and Racial/Ethnic Differences in Use of Outpatient Mental Health and Substance Use Services by Depressed Adults. Psychiatr Q 2006; 77: 211-22.

33. Martins AMEBL, Barreto SM, Pordeus IA. Auto-avaliação de saúde bucal em idosos: análise com base em modelo multidimensional. Cad Saúde Pública 2009; 25: 421-35.

34. Matos DL, Lima-Costa MF. Auto-avaliação da saúde bucal entre adultos e idosos residentes na Região Sudeste: resultados do Projeto SB-Brasil, 2003. Cad Saúde Pública 2006; 22: 1699-707.

35. Davidson PL, Andersen RM. Determinants of dental care utilization for diverse ethnic and age groups. Adv Dent Res 1997; 11: 254-62.

36. Manski RJ, Goodman HS, Reid BC, Macek MD. Dental Insurance Visits and Expenditures Among Older Adults. Am J Public Health. 2004; 94: 759-64.
37. Bós AMG, Bós AJG. Determinantes na escolha entre atendimento de saúde privada e pública por idosos. Rev Saúde Pública 2004; 38: 113-20.

38. MacEntee Ml, Stolar E, Glick N. Infiuence of age and gender on oral health and related behaviour in an independent elderly population. Community Dent Oral Epidemiol 1993; 21: 234- 9.

39. Kramer PF, Ardenghi, TM, Ferreira S, Fischer, LA, Cardoso L, Feldens CA . Utilização de serviços odontológicos por crianças de 0 a 5 anos de idade no município de Canela, Rio Grande do Sul, Brasil. Cad Saúde Pública 2008; 24: 150-6.

40. Moreira RS, Nico LS, Tomita NE, Ruiz T. A saúde bucal do idoso brasileiro: revisão sistemática sobre o quadro epidemiológico e acesso aos serviços de saúde bucal. Cad Saúde Pública 2005; 21:1665-75.

41. Pereira CRS, Patrício AAR, Araújo FAC, Lucena EES, Lima KC, Roncalli AG. Impacto da Estratégia Saúde da Família com equipe de saúde bucal sobre a utilização de serviços odontológicos. Cad Saúde Pública 2009; 25: 985-96.

42. Rocha RACP, Goes PSA Comparação do acesso aos serviços de saúde bucal em áreas cobertas e não cobertas pela Estratégia Saúde da Família em Campina Grande, Paraíba, Brasil. Cad Saúde Pública 2008; 24: 2871-80.

43. Rothman KJ, Greenland S. Modern epidemiology. 2nd ed. Philadelphia, USA: Lippincott Williams \& Wilkins; 1998.

Received on: 01/21/13

Final version presented on: 06/24/13

Accepted on: 09/13/13 